\title{
Small-scale Gravity Waves in the Lower Stratosphere Revealed by the MU Radar Multi-beam Observation
}

\author{
By Kaoru Sato and Isamu Hirota \\ Department of Geophysics, Faculty of Science, Kyoto University \\ Kyoto 606, Japan. \\ (Manuscript received 11 March 1988, in revised form 14 October 1988)
}

\begin{abstract}
A multi-beam measurement of winds in the troposphere and lower stratosphere was performed in January 1986 by the MU radar. Twelve beams were used to scan the wind field zonally through the zenith angle from $-30^{\circ}$ to $30^{\circ}$. Analy sing the observation data with high horizontal resolution, we have investigated the small horizontal structure of the wind for the first time.

An analysis was made of remarkably strong oscillations of the vertical wind component with a large vertical scale which appeared in the lower stratosphere. Assuming the local wind homogeneity over any neighboring two beam positions in the zonal scan, we make a horizontal time section, which shows that the oscillations are zonally monochromatic. The line-of-sight velocities are fitted to a wavelike structure at each height by the least-squares method, and it is found that the zonal wavelength is $5-30 \mathrm{~km}$. According to the phase difference between the zonal and vertical components, it is likely that the oscillations are due to internal gravity waves. The zonal phase veolcity is very small $(1-5 \mathrm{~m} / \mathrm{s})$ compared with the background wind $(\approx 50 \mathrm{~m} / \mathrm{s})$, indicating that the waves are almost at rest relative to the ground, like a topographic wave. Another interesting feature is that the zonal wavelength changes with height, suggesting that the oscillations are not simply due to a monochromatic gravity wave, but have a complicated three-dimensional structure.
\end{abstract}

\section{Introduction}

VHF Doppler radar is one of the most powerful tools to measure the fine structure of winds in the troposphere and lower stratosphere. Instantaneous measurements over a height range of several ten kilometers are possible by radar, in contrast to radiosonde observations which take over an hour for the same height range. The repetition of such measurements provides us with a time-height cross section of winds with the high time-resolution of about one minute. It also has good height resolution of a few hundred meters along the beam direction. Through VHF radar observations we can obtain information about small-scale phenomena in the atmosphere such as gravity waves.

(C) 1988, Meteorological Society of Japan
Estimation of parameters characterizing the horizontal structure of gravity waves is important for the examination of their effect on the largescale circulation as well as for the investigation of their origin. In many cases, however, their horizontal structure has been inferred from vertical structure with the aid of theoretical consideration, e.g, the dispersion relation, because the number of beams, directed for one measurement is limited by the usual radar system. One of the direct methods for determining the horizontal structure was developed by Vincent and Reid (1983): They use two beams with the same zenith angle in opposite directions, and obtain the horizontal wavelength from the cross-spectrum of the two line-of-sight velocities. In their method, however, the analysis for transient waves is difficult, and the accuracy de- 
creases when the horizontal wavelength is much larger or smaller than the distance between data points, and/or when the time-span of observation is not long enough to calculate the cross-spectrum.

The MU radar operated by the Radio Atmospheric Science Center (RASC) of Kyoto University (Fukao et al., 1985a,b) has the unique ability to measure the line-of-sight velocity almost simultaneously with up to 16 beam directions, which is suitable for the detection of the horizontal structure. Therefore, in the present study, an attempt was made to use the multibeam technique for investigating the nature of wind fluctuations with small horizontal scales.

The details of the observation are mentioned in Section 2, and the method of data analysis is described in Section 3. In Section 4, the characteristic features of the oscillation observed in the vertical wind are described in detail. Section 5 summarizes the results as concluding remarks.

\section{Observation}

The wind measurement in the troposphere and lower stratosphere was carried out on 22-24 in January 1986, by using the fast beam steerability of the MU radar. The observation period was 47.5 hours.

The antenna beam was pointed to 15 direction switched alternately from one pulse to another during the observation (Fig. 1). Twelve beams out of 15 were directed in the sector area from $30^{\circ}$ west of the zenith to $30^{\circ}$ east to scan the zonal wind field. Zenith angles smaller than $10^{\circ}$ were not chosen because measurements around the zenith do not give the exact line-ofsight velocities due to the effect of "aspect sensitivity" (Tsuda et al., 1986). Since the MU radar has the beam width of $3.6^{\circ}$, independent data are obtained for each beam position at the $4^{\circ} \mathrm{s}$ interval of the zenith angle in each direction. Two beams were tilted to north and south by $14^{\circ}$ from the zenith to measure the meridional wind, and the remaining beam was directed vertically to measure the vertical velocity.

The frequency spectra of the atmospheric echo were obtained for the height range of 2.4 . $24.6 \mathrm{~km}$. The height resolution is about $300 \mathrm{~m}$

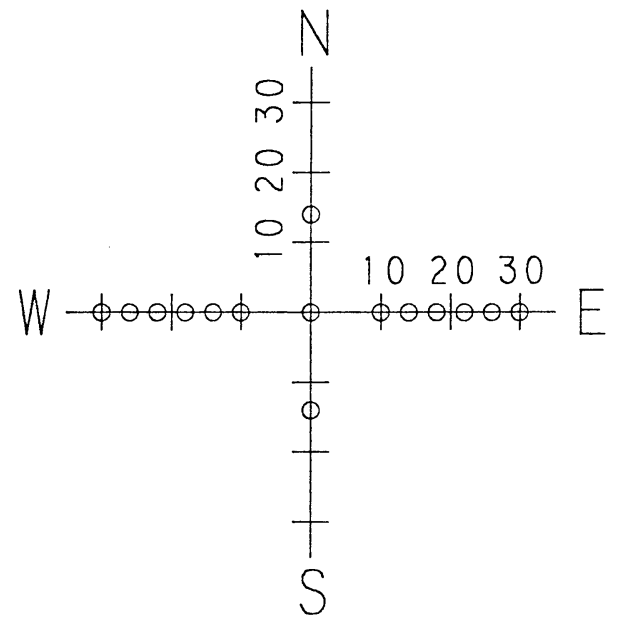

Fig. 1. The beam directions (represented by open circles). The figures show the zenith angle.

along the radar beam and the time resolution of this study is about 7 minutes because of the integration of weak echoes.

The line-of-sight velocity was obtained by fitting the spectral data to a Gaussian-shaped spectrum using the least-squares method. The nominal resolution of the line-of-sight velocity corresponding to the interval of FFT points of the spectra was about $0.5 \mathrm{~m} / \mathrm{s}$. The actual resolution, however, is less than $0.1 \mathrm{~m} / \mathrm{s}$ for the spectra data having a high "signal-to-noise ratio" $(\mathrm{S} / \mathrm{N})$ (Yamamoto et al., 1988). The reliability of the data was checked using the detectability in the $\mathrm{S} / \mathrm{N}$ and statistical fluctuations, fitting accuracy, and both temporal and spatial continuity. Since the beams are radiated from the observation point, the line-of-sight velocity is referred to as "radial velocity" hereafter.

During this observation period a typical midwinter pattern with a strong subtropical jet was situated synoptically over Japan. No convective clouds were observed above the MU radar site.

\section{Data Analysis}

The radial velocity $V$ is expressed as

$$
V_{\theta}(z, t)=u_{\theta}(z, t) \cdot \sin \theta+w_{\theta}(z, t) \cdot \cos \theta
$$

where $\theta$ is the zenith angle of the beam, $z$ is the altitude, $t$ is the time, $u$ is the horizontal component of wind, and $w$ is the vertical 
component.

The original data obtained at constant radial distances from the radar are converted to those at constant heights, using a simple linear interpolation.

Assuming that the $u$ and $w$ contributing to the $V$ 's of neighboring two beams are equal but different from those of the other beam pairs, we have

$$
\begin{aligned}
& u_{\theta_{12}}(z, t)=\frac{V_{\theta_{1}}(z, t) \cos \theta_{2}-V_{\theta_{2}}(z, t) \cos \theta_{1}}{\sin \left(\theta_{1}-\theta_{2}\right)}, \\
& w_{\theta_{12}}(z, t)=\frac{V_{\theta_{1}}(z, t) \sin \theta_{2}-V_{\theta_{2}}(z, t) \sin \theta_{1}}{-\sin \left(\theta_{1}-\theta_{2}\right)},
\end{aligned}
$$

where $\theta_{12}=\left(\theta_{1}+\theta_{2}\right) / 2$. This method provides us with the horizontal variation of $u$ and $w$. However, it has the defect of amplifying the error in $V$ because $\sin \left(\theta_{1}-\theta_{2}\right)$ in the denominator is small in this analysis.

On the other hand, to obtain the locally averaged wind velocity, Vincent and Reid (1983)'s method is useful, which uses two beams with equal and opposite angles $\theta$ to the zenith in such a way that,

$$
\begin{aligned}
& {[u(z, t)]_{\theta}=\frac{V_{\theta}(z, t)-V_{-\theta}(z, t)}{2 \sin \theta},} \\
& {[w(z, t)]_{\theta}=\frac{V_{\theta}(z, t)+V_{-\theta}(z, t)}{2 \cos \theta} .}
\end{aligned}
$$

Furthermore, in this study the following value is adopted as a rough measure of the spatial variation in zonal winds:

$\left[\left|u^{\prime}(t ; z)\right|\right]$

$=\sqrt{\frac{1}{N} \sum_{n=1}^{N}\left(\frac{V_{\theta_{n}}(z, t)-V_{-\theta_{n}}(z, t)}{2 \sin \theta_{n}}-[u(t ; z)]\right)^{2}}$,

where $N$ is the total number of symmetrical beam pairs, $\theta_{n}$ is the zenith angle of the $n$ 'th beam pair, and $[u(t ; z)]$ is the averaged zonal velocity in the zonal scan, that is

$$
[u(t ; z)]=\frac{1}{N} \sum_{n=1}^{N}[u(z, t)]_{\theta_{n}} .
$$

\section{Results and Discussion}

Figure 2 shows the $w$-component of wind measured by the vertical beam through the whole observation period. The components having a period less than 1 hour were removed using a low-pass filter. The regions of the velocity whose absolute value is more than $0.5 \mathrm{~m} / \mathrm{s}$, are hatched. Conspicuous strong oscillations with large vertical scale and with 1-2 hour period are found around the beginning and the end of the observation period. According to the spectral analysis, the oscillations appear mainly above the height of the sub-tropical jet $(\approx 12 \mathrm{~km})$. Although such large vertical wind fluctuations have been observed frequently using other VHF radars, such as Poker Flat, Alaska; Sunset, Colorado; or three closely-spaced radars near Nimes, Southern France (e.g. Ecklund et al., 1981, 1982, 1985), a detailed analysis (including horizontal structure) has not yet been fully made.

The zonal variability of the $u$-component of wind velocity calculated from (4) is shown in Fig. 3. The hatched regions having more than $4 \mathrm{~m} / \mathrm{s}$ correspond well to the region of the pronounced oscillation shown in Fig 2, suggesting that this oscillation has a small-scale zonal structure.

In this study the distinct events surrounded by the two rectangles in Fig. 2 are analysed. The first event, which appeared on the $22 \mathrm{nd}$ is referred to as $\mathrm{J} 22$, and the next one on the 24th as $\mathrm{J} 24$ hereafter. The data used for analysis are the wind components with 1-2.5 hour periods and with vertical scales of more than $0.9 \mathrm{~km}$ obtained using a bandpass filter for time and a lowpass filter for height, respectively.

\subsection{Time-Height cross section}

Each component for $\mathbf{J} 22$ and $\mathbf{J} 24$ is represented in Figs. 4.1 and 4.2, respectively. The hor1zontal components were calculated from (3-a) with the radial velocities of the two symmetrical beams nearest to the zenith usually being employed. As seen in the figures, these oscillations continue only for several hours. Then the two events are further divided into the first and second halves, which are referred to as 


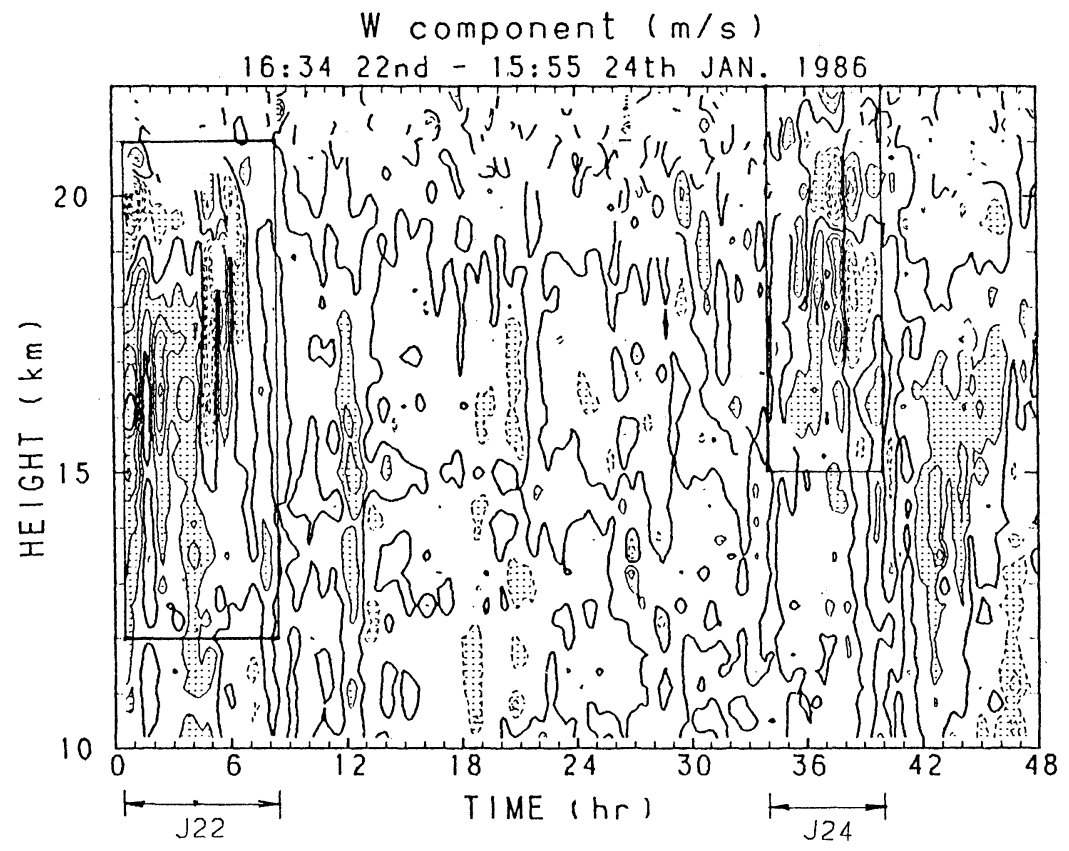

Fig. 2. w-component of wind velocity measured with the vertical beam and low-pass filtered with a cut-off length of 1 hour. The contour interval is $0.5 \mathrm{~m} / \mathrm{s}$. Hatches show the regions of the velocity whose absolute value is more than $5 \mathrm{~m} / \mathrm{s}$.

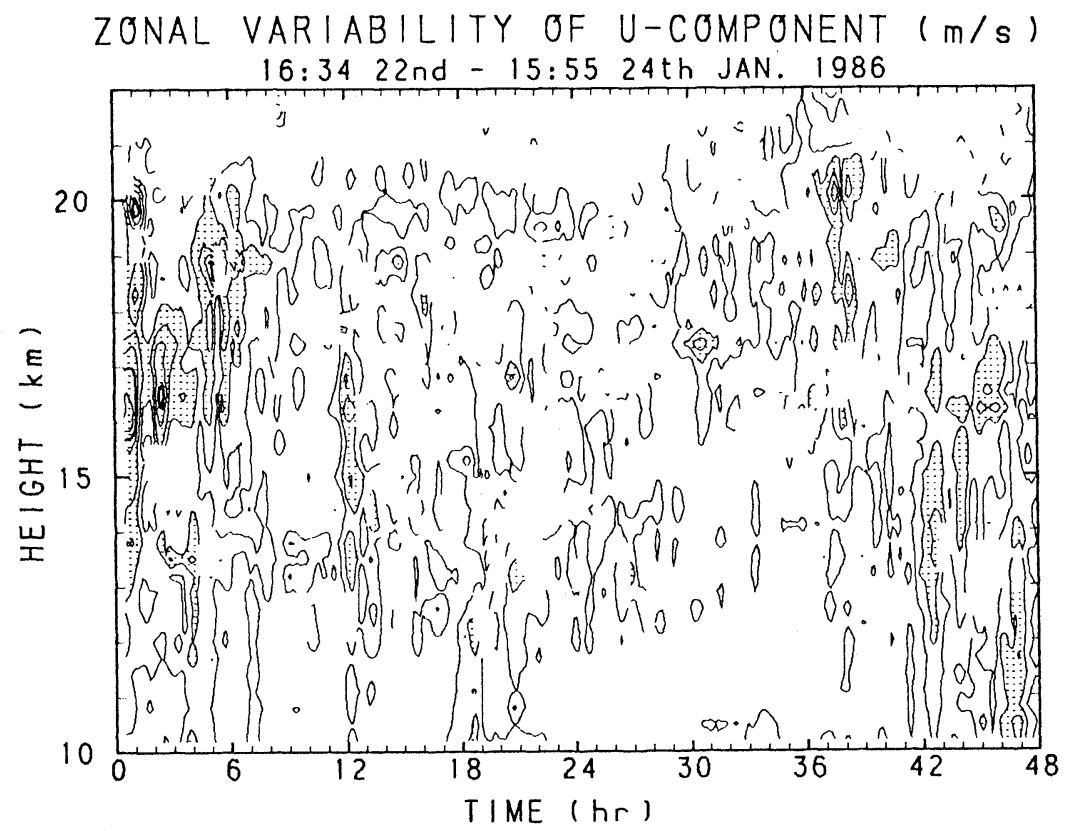

Fig. 3. Spatial variability of zonal wind velocity. Contour interval is $2 \mathrm{~m} / \mathrm{s}$. Regions with magnitude of more than $4 \mathrm{~m} / \mathrm{s}$ are hatched. 
J22-a (17:04-18:48 LST on the 22nd), J22-b (20:31-22:37 LST on the 22nd) for J22, and J24-a (03:07-04:36 LST on the 24th), J24-b (05:35-07:04 LST on the 24th) for J24.

The phase differences between wind components are important parameters for identifying the oscillation. Judged from its large vertical scale and short period, these oscillations are likely to be due to internal gravity waves. Internal gravity waves must have a phase difference of 0 or 180 degrees between $u$ and $w$. In Fig. 4, however, $u$ seems to be out of phase with $w$ by almost 90 degrees. This might be caused by the invalidity of the assumption that the wind field is homogeneous at each height position measured by two symmetrical beams, in the case of the waves having a small horizontal scale.

Figure 5 shows the $w$ component obtained from (3-b) for each symmetrical beam pair in the zonal scan for $\mathbf{J} 22$-a. At the beginning $w$ is
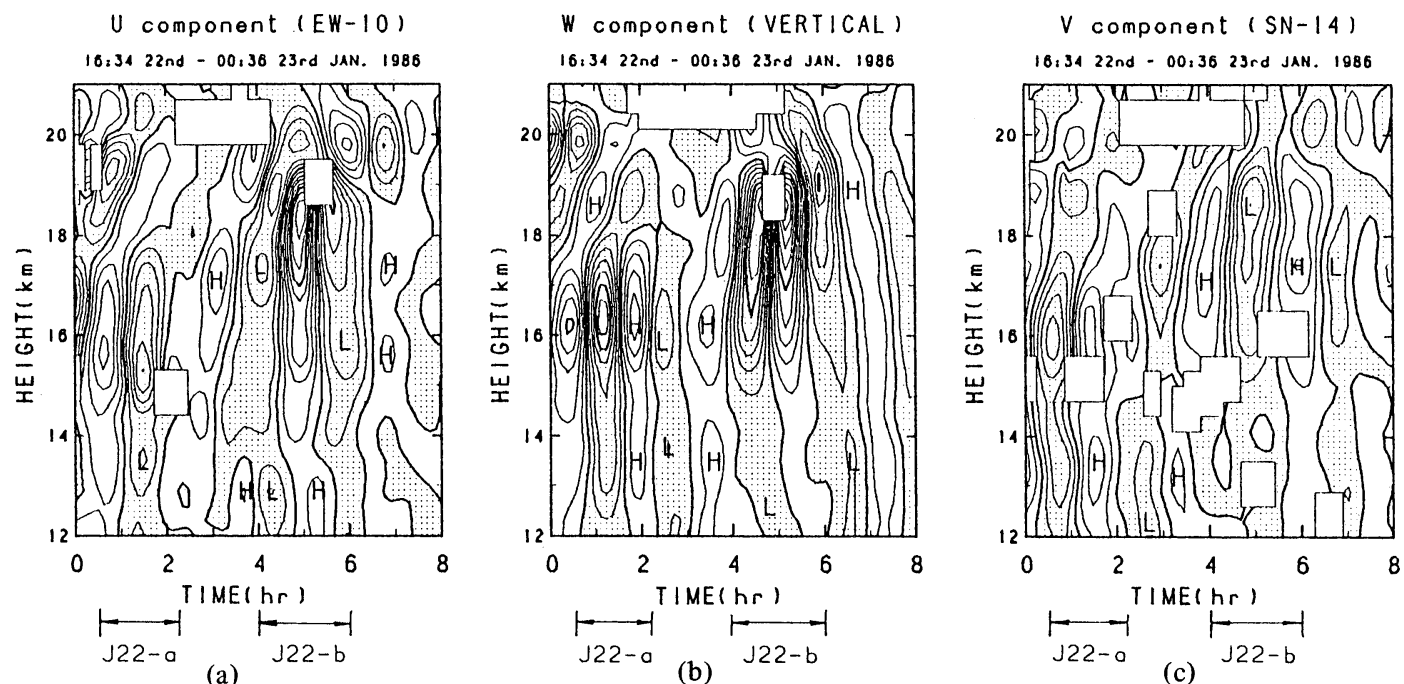

Fig. 4.1.Hight-time cross section of $\mathrm{J} 22$ event. (a) $u$-component and (c) $v$-component calculated using (3-a), and (b) $w$-component measured with vertical beam. The contour interval is $1 \mathrm{~m} / \mathrm{s}$ for $u$ and $v$, and $0.2 \mathrm{~m} / \mathrm{s}$ for $w$.

$U$ component ( EW-10)

$02,00-08: 02$ 24th JAN. 1886

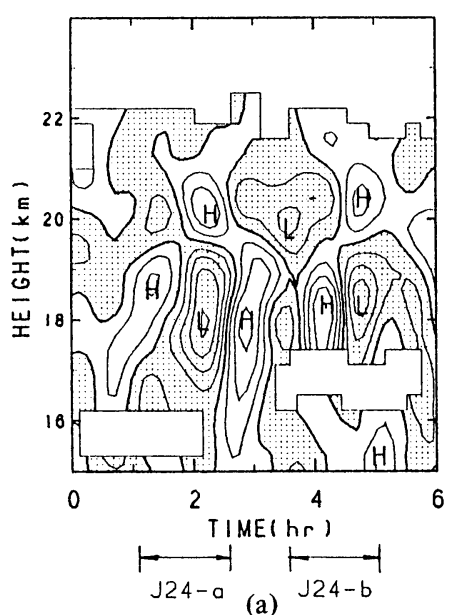

W component (VERTICAL) $02,00-08,0224$ th JAN. 1980

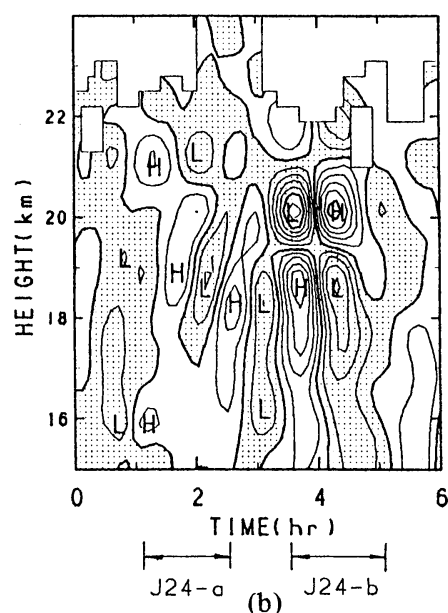

$V$ component $(\mathrm{SN}-14)$

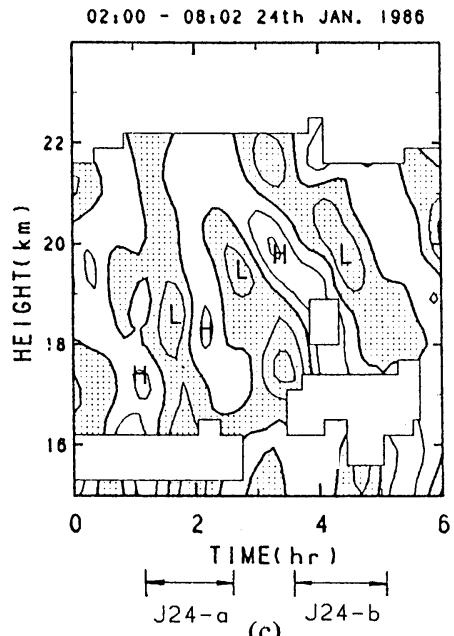

Fig. 4.2. The same as Fig. 4.1 but for $\mathrm{J} 24$. 


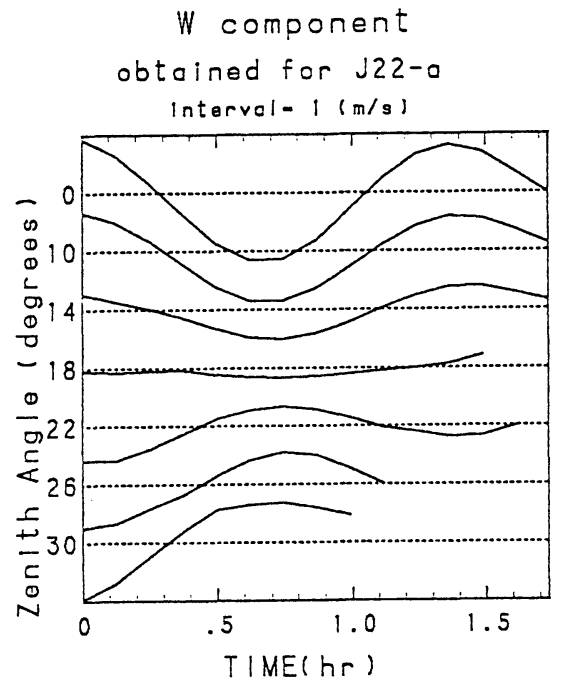

Fig. 5. $w$-component at the height of $15.9 \mathrm{~km}$ for J22-a calculated using (3-b) for each symmetrical beam pair in the zonal scan.

about $1 \mathrm{~m} / \mathrm{s}$ for measurement of the vertical beam, and decreases with increasing zenith angle of the beam pair, reversing the sign at $18^{\circ}$ This indicates that the wind field is not uniform in the zonally scanned region. Therefore, Fig. 4 does not show the phases and amplitudes of $u$ and $w$ correctly.

\subsection{Horizontal-time section}

In order to examine the zonal structure, we obtained $u$ and $w$ from radial velocities of neighboring beam pairs using (2-a) and (2-b).

Figures 6.1 and 6.2 show the horizontaltime section for $\mathrm{J} 22$ and $\mathrm{J} 24$, respectively. The heights $(15.9,18.0,19.2$, and $17.7 \mathrm{~km}$ for each event) are chosen where the oscillation is found distinctly. Continuous monochromatic wavelike phase is found, migrating eastward for $\mathbf{J} 22-\mathrm{a}, \mathbf{J} 24-\mathrm{a}$ and $\mathbf{J} 24-\mathrm{b}$, and westward for $\mathbf{J} 22-\mathrm{b}$. However the magnitude of $w$ is very large compared with that measured by the vertical beam. The assumption of homogeneity of the wind field between neighboring two beam positions may be invalid for the small-scale horizontal variations.

Thus a simple simulation was made in order to examine the effect induced by inhomogeneity. The assumed wavelike structure is

$$
\left.\begin{array}{l}
u=8 \cos \left(\frac{2 \pi}{\lambda_{x}} x-\frac{2 \pi}{T} t\right) \\
w=2 \cos \left(\frac{2 \pi}{\lambda_{x}} x-\frac{2 \pi}{T} t\right)
\end{array}\right\}
$$

where $x$ is zonal coordinate, $\lambda_{x}=10 \mathrm{~km}$ and $\mathrm{T}=2$ hr. We simulated the "observation" of the assumed wave (5) by using (2-a) and (2-b) (Fig. 7). Although the "observed" wave amplitude and phase are not represented correctly, the zonal wavelength and the period are well reproduced, as well as the sense of the phase difference between $u$ and $w$. Therefore the zonal wavelength $\lambda_{x}$ for each event can be estimated from Figs. 6.a and 6.2 as follows:

$$
\begin{array}{ll}
\mathrm{J} 22-\mathrm{a}: & \lambda_{x} \sim 23 \mathrm{~km} ; \\
\mathrm{J} 22-\mathrm{b}: & \lambda_{x} \sim 16 \mathrm{~km} ; \\
\mathrm{J} 24-\mathrm{a}: & \lambda_{x} \sim 5.8 \mathrm{~km} ; \\
\mathrm{J} 24-\mathrm{b}: & \lambda_{x} \sim 13 \mathrm{~km} .
\end{array}
$$

\subsection{Fitting analysis}

In order to examine the phase difference between $u$ and $w$, we fit the radial velocities to a monochromatic wavelike structure of the wind using the least-squares method, which can represent phases exactly.

Thirteen radial velocities measured in the eastwest scan at each time and height are used for fitting to the shape of

$$
\begin{aligned}
& V_{\theta_{i}}(z)= u_{0} \sin \left(\frac{2 \pi}{\lambda_{x}} x_{i}+\varphi_{u}\right) \cdot \sin \theta_{i} \\
&+w_{0} \sin \left(\frac{2 \pi}{\lambda_{x}} x_{i}+\varphi_{w}\right) \cdot \cos \theta_{i}, \\
& x_{i}=z \cdot \tan \theta_{i} .
\end{aligned}
$$

We assume that the wind components except for those of the wavelike structure (6) have already removed from the radial velocities using the time and height filters mentioned at the first part of Section 4 . In order to decrease the nonlinearity of the fitting function, unknown parameters are reduced to four: $u_{0}, w_{0}, \varphi_{n}$, and $\varphi_{w}$. Fitting is made by changing $\lambda_{x}$ (zonal wavelength) continuously near the values estimated in Section 4.2 , to find the $\lambda_{x}$ having the minimum fitting 

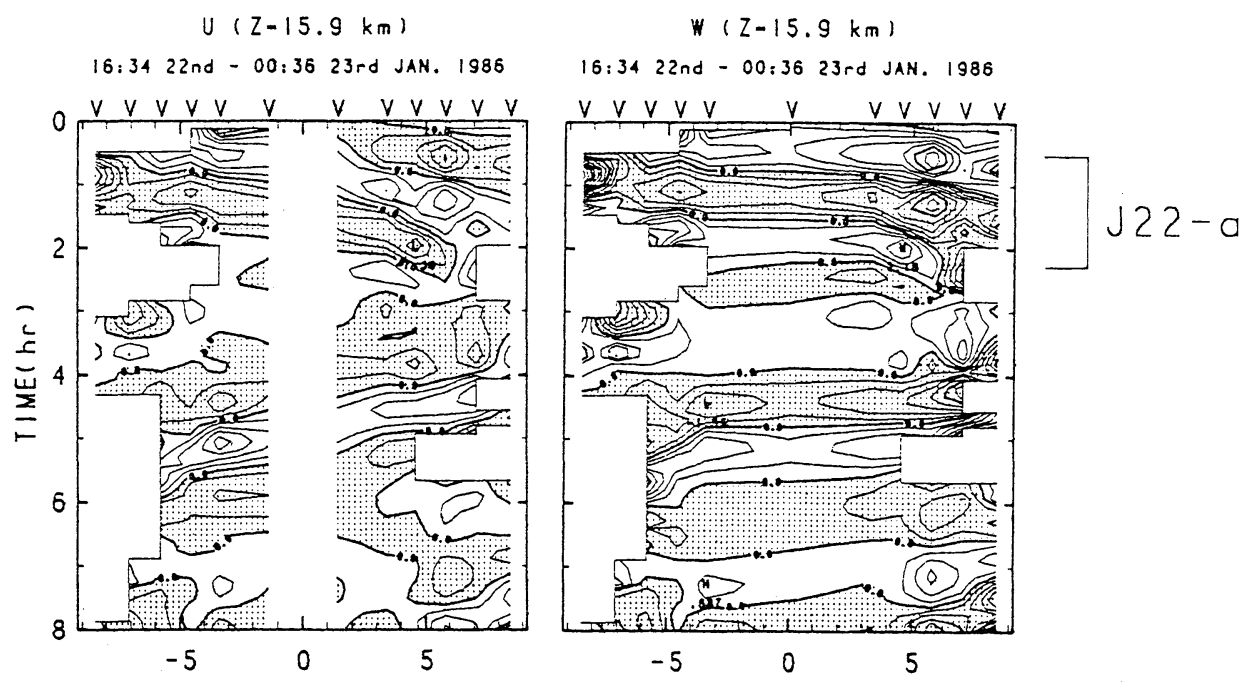

$U(Z-18.0 \mathrm{~km})$

$W(Z-18.0 \mathrm{~km})$

$16: 34$ 22nd $-00: 36$ 23rd JAN. 1986
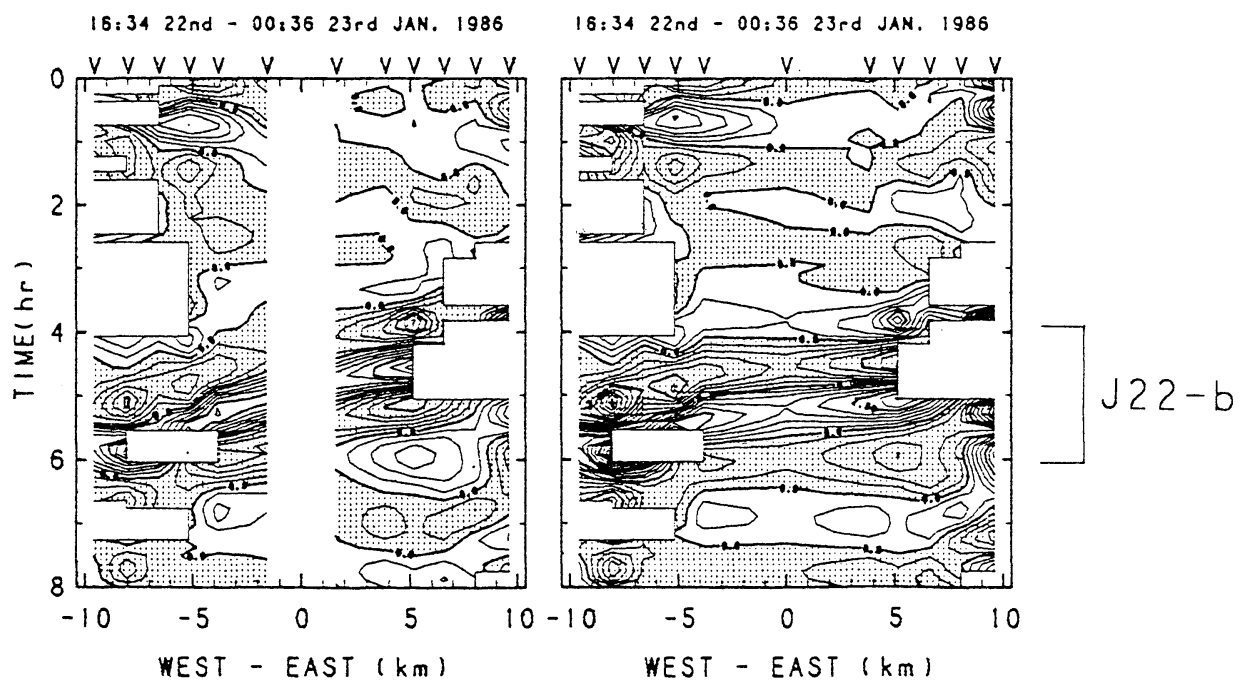

Fig. 6.1. Horizontal-time section for J22. $u$ and $w$ are calculated using (2-a) and (2-b), respectively. The contour interval is $2 \mathrm{~m} / \mathrm{s}$ for $u$, and $0.5 \mathrm{~m} / \mathrm{s}$ for $w$. The horizontal axis shows the scanned range. V's show data points.

residual. It is noted that this method of the fitting analysis is suitable for transient waves since the assumed structure (6) has no time parameters.

Figure 8 shows the time-averaged standard deviation (S.D., the square root of the residual) as a function of the zonal wavelength for the case of J22-a. The zonal wavelength $\lambda_{x}^{*}$ corresponding to the minimum value of S.D. is found for each profile. All minimum S.D. values are about 0.1 $\mathrm{m} / \mathrm{s}$ which are within the accuracy of the data. This is the same for the other cases, indicating that the oscillations are zonally sinusoidal.

It is noteworthy that $\lambda_{x}^{*}$ is not constant with height (Fig. 8). This is also the case with J22-b. It follows that the structure of these oscillations 

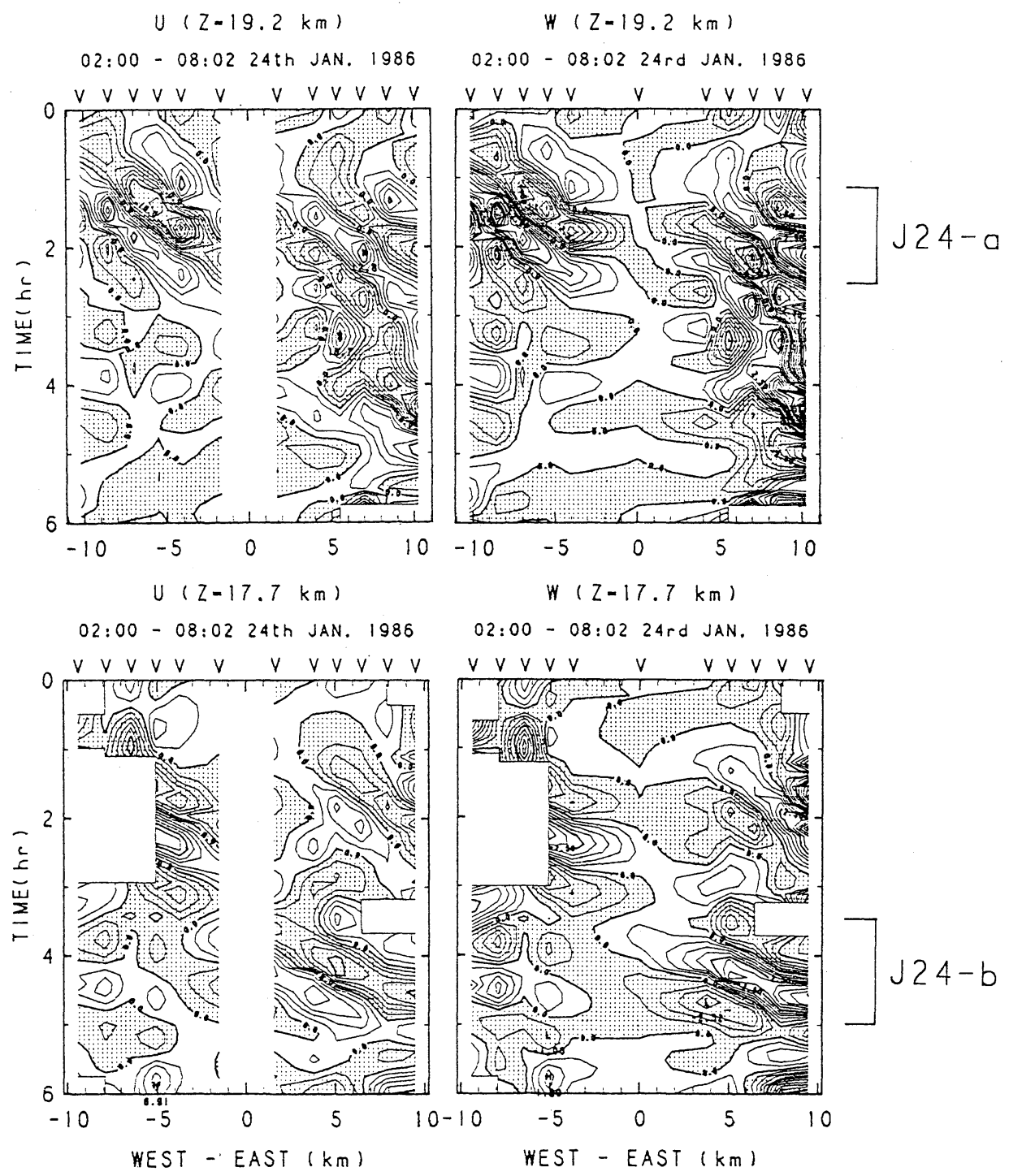

Fig. 6.2. The same as Fig. 6.1 but for $\mathrm{J} 24$.

changes three-dimensionally in their large vertical structures.

S.D.s were further averaged over the height range where the zonal wavelength could be regarded as constant. As a result, the zonal wavelength $\lambda_{x}^{*}$ for each event is estimated as follows:
$\mathrm{J} 22-\mathrm{a}: \quad \lambda_{x}^{*}=22-27 \mathrm{~km} \quad(z=15.6-16.2 \mathrm{~km})$, $\lambda_{x}^{*}=17-19 \mathrm{~km} \quad(z=16.8-17.4 \mathrm{~km})$;

$\mathrm{J} 22-\mathrm{b}: \quad \lambda_{x}^{*}=17-20 \mathrm{~km} \quad(z=17.7-18.0 \mathrm{~km})$;

J24-a : $\quad \lambda_{x}^{*}=6-7 \mathrm{~km}(z=18.6-19.5 \mathrm{~km})$;

J24-b : $\lambda_{x}^{*}=11-12 \mathrm{~km}(z=17.4-18.0 \mathrm{~km})$, $\lambda_{x}^{*}=14-16 \mathrm{~km} \quad(z=18.6-19.2 \mathrm{~km})$. 

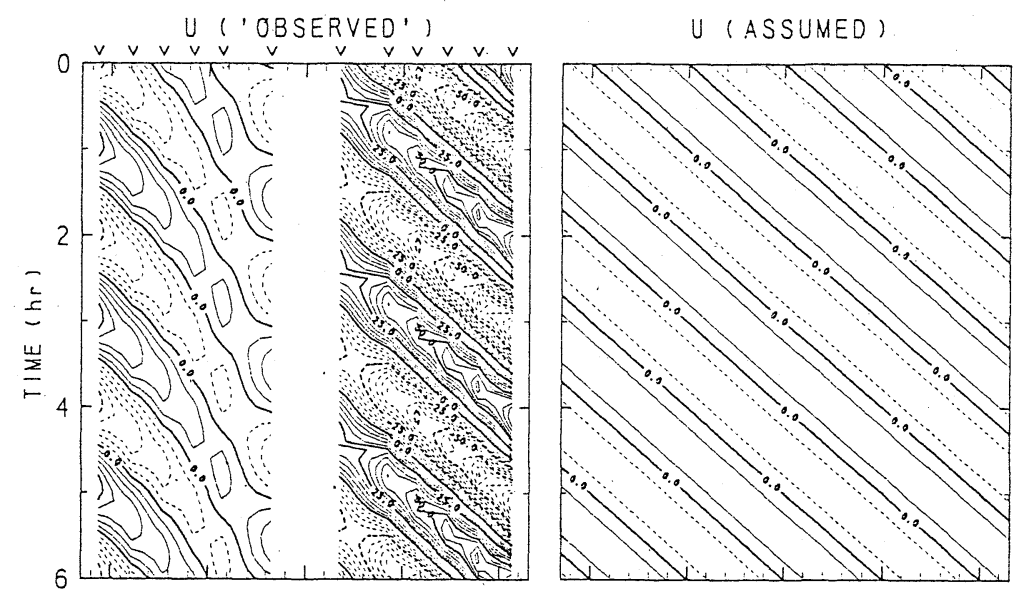

CONTOUR INTERVAL - $5 \mathrm{~m} / \mathrm{s}$
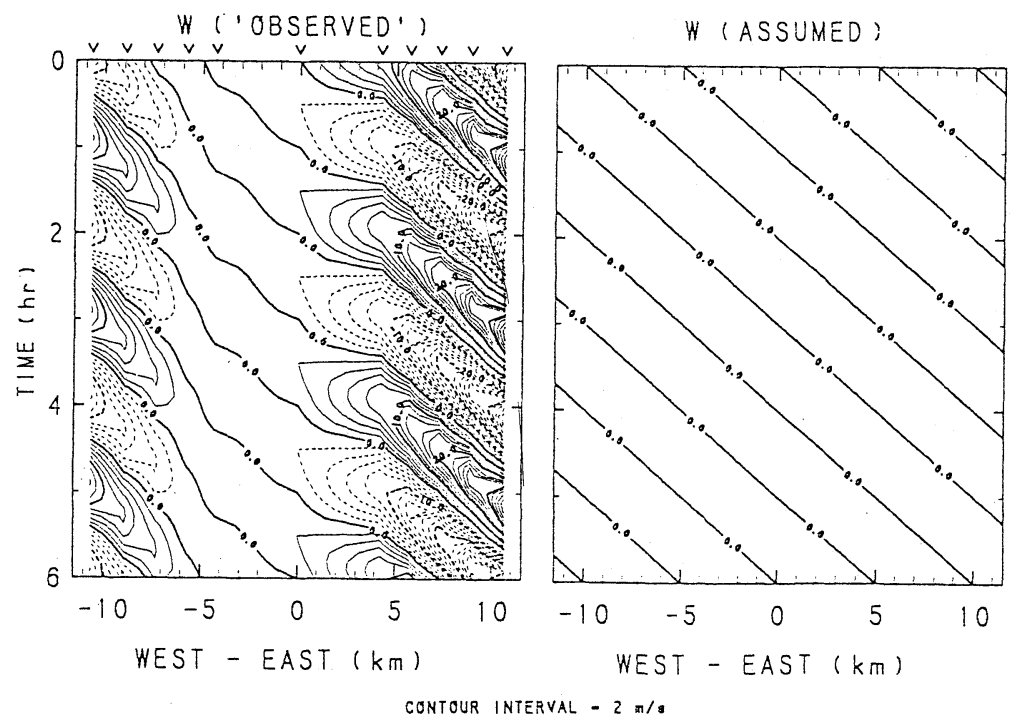

Fig. 7. Simulation of wind velocity field at the height of $20 \mathrm{~km}$, calculated using (2-a) and (2-b). Right figures show the assumed wave structures. Left figures show the "observed" ones.

These values are consistent with those estimated using the horizontal-time section of the wind field in the previous section.

The histograms of the phase difference $\Delta \Phi=\varphi_{u}-\varphi_{w}$ associated with $\lambda_{x}^{*}$ are shown in Fig. 9. The distributions of $\Delta \Phi$ for all events have peaks near 0 or 180 degrees, except for $\mathrm{J} 22-\mathrm{a}$ at the height range of $16.8-17.4 \mathrm{~km}$. Therefore it can be said that these phenomena are due to internal gravity waves.
In order to confirm that the oscillations are also sinusoidal in time, we made the fit including a time parameter, i.e., period $T$. The assumed function is as follows:

$$
\begin{aligned}
V_{\theta_{i}}(z)= & u_{0} \sin \left(\frac{2 \pi}{\lambda_{x}} x_{i}-\frac{2 \pi}{T} t+\varphi_{u}\right) \cdot \sin \theta_{i} \\
& +w_{0} \sin \left(\frac{2 \pi}{\lambda_{x}} x_{i}-\frac{2 \pi}{T} t+\varphi_{w}\right) \cdot \cos \theta_{i} .
\end{aligned}
$$




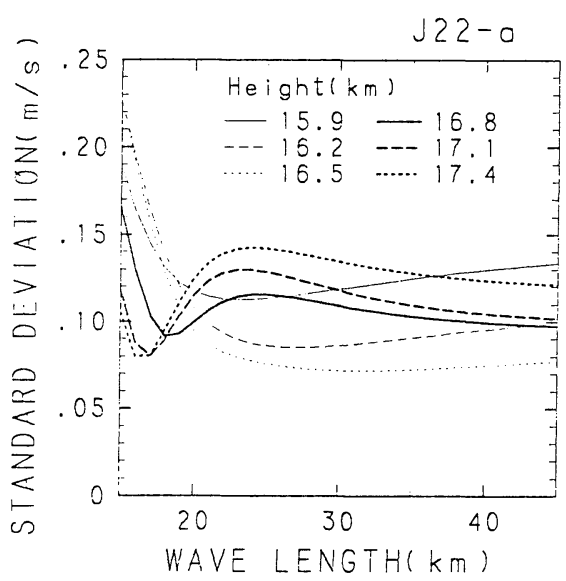

Fig. 8. Time averaged standard deviation for each zonal wavelength after fitting in J22-a.

Here the number of data points used for a fit is increased multiplicatively by the number of records. However, the parameters might not necessarily be evaluated more precisely by comparison with the previous fitting analysis, since we ignore the wave transiency in this analysis. The period is roughly estimated from Figs. 4-1 and 4-2. The number of unknown parameters is four as before, and $\lambda_{x}$ and $T$ are fixed in order to reduce the nonlinearity of the fitting. Then the $\lambda_{x}$ and $T$ with the minimum S.D. are found. The parameters obtained are represented in Table 1. The height for each event in Table 1 is chosen where the minimum S.D. becomes smallest among the height range with the similar zonal wavelength. The zonal wavelength and the phase differences are consistent with those obtained by the previous fitting analysis, indicating that the oscillations are sinusoidal in time as well as zonally.

Through these two types of fitting analysis, we confirm that the oscillations are due to internal gravity waves. The zonal phase velocity estimated from $\lambda_{x}$ and $T$ in Table 1 is $1.5 \mathrm{~m} / \mathrm{s}$, which is very weak compared with the background wind $(\approx 50 \mathrm{~m} / \mathrm{s})$. This suggests that the waves are almost at rest relative to the ground as in the case of the mountain wave. However, since no considerable high mountains exist near the radar site, and the oscillations appeared distinctly in the lower stratosphere, it is difficult to identify them as a mountain waves.

\section{Concluding remarks}

Multi-beam observation of wind components in the troposphere and lower stratosphere was performed using the MU radar. By analysing the data with high horizontal resolution, we have investigated the fine-scale spatial structure of the wind field for the first time.

During the observation period, conspicuous strong oscillations of the vertical wind component were detected. The results of a detailed analysis confirm that these oscillations are due to internal gravity waves. The characteristic features are summarized as follows:

(1) The vertical oscillations appear above the strong westerly jet in the lower stratosphere, and have a large vertical scale of about $5 \mathrm{~km}$ and a short period of $1-2$ hours.

(2) The oscillations show zonally monochromatic aspects at each height. The zonal wavelength is $5-25 \mathrm{~km}$. The phase differences between $u$ and $w$ are $0^{\circ}$ or $180^{\circ}$.

(3) The zonal wavelength changes in the large

Table 1. Parameters for each event obtained by the fitting analysis including a time parameter

\begin{tabular}{ccccccc}
\hline Event & $\begin{array}{c}\text { Height } \\
(\mathrm{km})\end{array}$ & $\begin{array}{c}u_{0} \\
(\mathrm{~m} / \mathrm{s})\end{array}$ & $\begin{array}{c}w_{0} \\
(\mathrm{~m} / \mathrm{s})\end{array}$ & $\begin{array}{c}\lambda_{x} \\
(\mathrm{~km})\end{array}$ & $\begin{array}{c}\mathrm{T} \\
\text { (hours) }\end{array}$ & $\begin{array}{c}\Delta \Phi \\
\text { (degrees) }\end{array}$ \\
\hline $\mathrm{J} 22-\mathrm{a}$ & 15.9 & 0.58 & 0.73 & 22.1 & 1.51 & 172 \\
& 17.4 & 1.5 & 0.46 & 15.5 & 1.51 & -94 \\
$\mathrm{~J} 22-\mathrm{b}$ & 18.0 & 1.2 & 0.82 & 17.9 & -1.51 & 47 \\
$\mathrm{~J} 24-\mathrm{a}$ & 19.2 & 0.09 & 0.47 & 6.2 & 1.05 & -151 \\
$\mathrm{~J} 24-\mathrm{b}$ & 17.7 & 0.97 & 0.46 & 11.7 & 1.46 & 31 \\
& 18.9 & 1.2 & 0.28 & 14.0 & 1.46 & -15 \\
\hline
\end{tabular}


J22-0

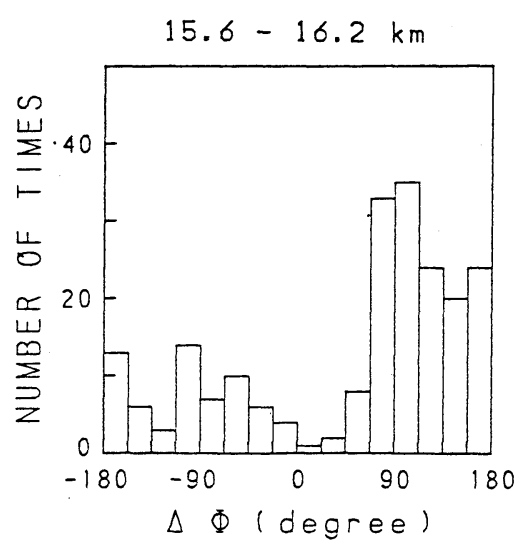

J22-b

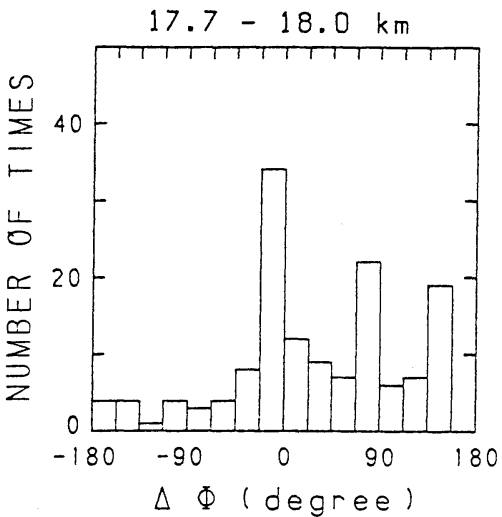

J24-b

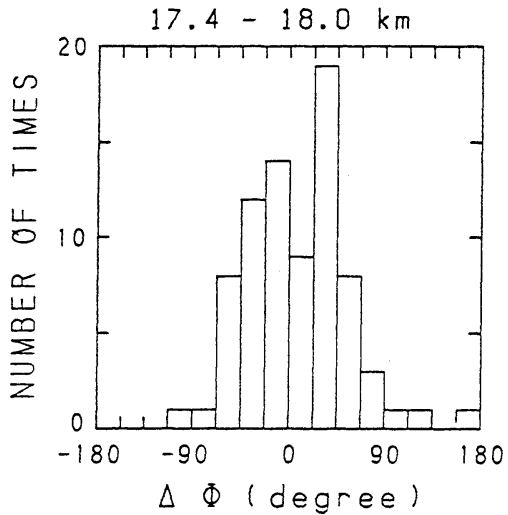

J22-o

$16.8-17.4 \mathrm{~km}$

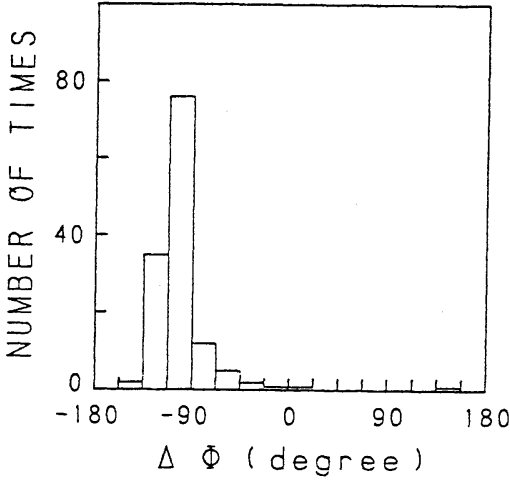

J24-a

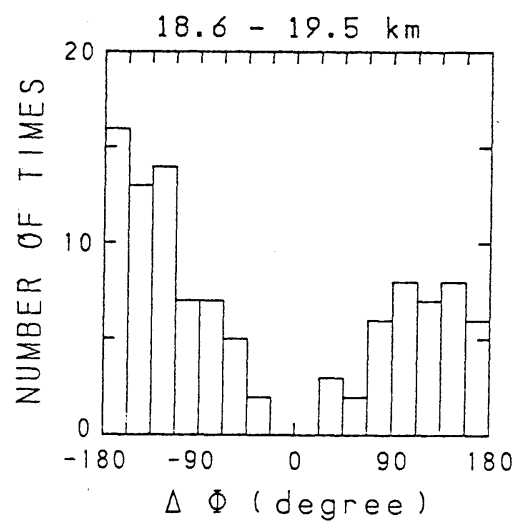

J24-b

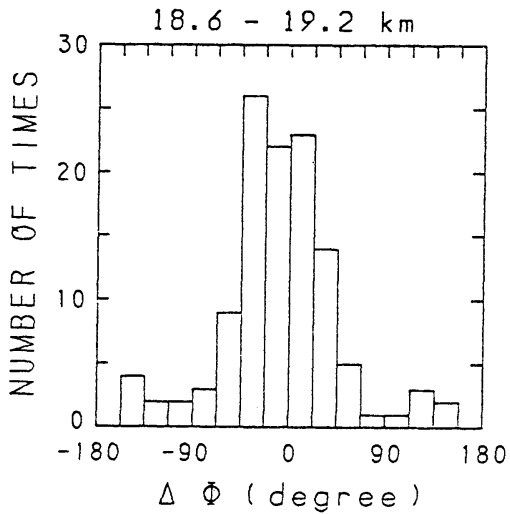

Fig. 9. Histograms of phase difference $\Delta \Phi=\varphi_{u}-\varphi_{w}$ after fitting for each events. 
vertical scale. It follows that the oscillations are not simply due to a monochromatic gravity wave but have complicated three dimensional structures.

(4) The gravity waves have a small zonal phase velocity of $1-5 \mathrm{~m} / \mathrm{s}$.

For further examination of their detailed structure, it is necessary to improve such multibeam observations. Both zonal and meridional scan of the wind field will be suitable for the detection of the detailed horizontal scale variation that the oscillations must have.

Strong vertical disturbances have often appeared in the observations using VHF radars. Most of those are not regarded as the simple oscillation having a single time-frequency as the case of this study, but as variations with a wide range of frequencies. The characteristics, frequency of occurrence, origin, effect on the mean flow, and the seasonal variation are all outstanding and interesting subjects which remain to be examined in detail about these disturbances. Continuation of the multi-beam observations promises to be of great importance.

\section{Acknowledgements}

This study was initiated when the one of the authors (K.S.) was a graduate student at the University of Tokyo, and she would like to thank Prof. T. Matsuno for his encouragement. We are also grateful to Dr. T. Sato for his useful advice and comments on performing the measurement and the data analysis. Contour maps were drawn using graphic programs of the
NCAR software support library. The MU radar belongs to and is operated by the Radio Atmospheric Science Center of Kyoto University.

\section{References}

Ecklund, W.L., K.S. Gage and A.C. Riddle, 1981: Gravity wave activity in vertical winds observed by the Poker Flat MST radar. Geophys. Res. Lett., 8, 265-288.

—, - B.B. Balsley, R.G. Strauch and J.L. Green, 1982: Vertical wind variability observed by VHF radar in the lee of the Colorado Rockies. Mon. Wea. Rev., 110, 1451-1457.

B.B. Balsley, D.A. Carter, A.C. Riddle, M. Crochet and R. Garello, 1985: Observation of vertical motions in the troposphere and lower stratosphere using three closely spaced ST radars. Radio Sci., 20, 1196-1206.

Fukao, S., T. Sato, T. Tsuda, S. Kato, K. Wakasugi and T. Makihira, 1985a: The MU radar with an active phased array system, 1. Antenna and power amplifiers. Radio sci., 20, 1155-1168.

, T. Tsuda, T. Sato, S. Kato, K. Wakasugi and T. Makihira, 1985b: The MU radar with an active phased array system, 2 . In-house equipment. Radio Sci., 20, 1155-1168.

Tsuda, T., T. Sato, K. Hirose, S. Kato and S. Fukao, 1986: MU radar observations of the aspect sensitivity of the backscattered VHF echo power in the troposphere and lower stratosphere. Radio Sci., 21, 971-980.

Vincent, R.A., and I.M. Reid, 1983: HF doppler measurements of mesospheric gravity wave momentum fluxes. J. Atmos. Sci., 40, 1321-1333.

Yamamoto, M., T. Sato, P.T. May, T. Tsuda, S. Fukao and S. Kato, 1988: Estimation error of spectral parameters of MST radar obtained by least squares fitting method and its lower bound. Radio Sci., in press. 


\title{
MU レーダー多数ビーム観測により検出された下部成層圏小規模内部重力波
}

\author{
佐藤薰 ·廣田勇 \\ (京都大学理学部地球物理学教室)
}

1986年 1 月 22日〜24日の48時間にわたり，MU (Middle and Upper atmosphere) レーダーを用いて， 対流圈・下部成層圏の風の多数ビームによる東西スキャン観測を行なった。これまでのVHFレーダー による大気重力波の観測では，ビーム数の制限から鉛直構造のみを調べることが多かったが，本研究で は，水平分解能の良い観測データを解析することで，風の場の水平微細構造を直接検出することを試み た。

観測期間中, 下部成層圏において, 鉛直スケールが長く $(\sim 7 \mathrm{~km})$, 周期 $1 \sim 2$ 時間の強い鉛直風振動 が見られた。そこで,この振動について詳しく解析を行なった。

まず, 高度方向にハイパスフィルター，時間方向にバンドパスフィルターをかけて振動成分を取り出 す。次に，隣り合ったビームの視線速度に寄与する風速は局所的に等しいとして東西時間断面目を作成 すると, この振動は東西に単色波的であり, 東西波長は 5 〜 30kmであることがわかった。このような水 平スケールの小さい現象に対してはビーム間の風の場の一様性が仮定できない。そこで，東西成分と鉛 直成分の位相差を求めるために，単色波を仮定し，東西断面に位置する13の視線速度を，それぞれの高 さについて最小二乗法によりフィッテングした。得られた位相差は重力波の理論から予測される值とよ く一致し，この振動が内部重力波によるものであることが確認できた。

東西位相速度は $1 \sim 5 \mathrm{~m} / \mathrm{s}$ であり背景風の約 $50 \mathrm{~m} / \mathrm{s}$ に比べて大変小さく, この振動が地面に対し て止まっていることがわかる。しかし，下部成層圈に顕著である点などから，山岳波であるかどらかは 断定できない。また，東西波長は高度方向に変化していることもわかった。この結果は，この振動が単 純に 1 つの単色重力波で構成されるのではなく, 複雑な三次元的構造を持つことを示唆している。今後 は，東西だけでなく南北にもスキャンする観測を行ない，この振動のより詳しい構造を調べる必要があ るとともに, 多くの観測データをもとに, 平均風への効果, 発生頻度, 季節変化などについて明らかに していく必要がある。 